\title{
References:
}

1. Акашева Т. В., Рахимова Н. М. Функциональная нагрузка сильных позиций текста и их прагматическая адаптация при переводе. Евразийский союз ученых. Филологические науки. 2014. № 7. С. 80-82.

2. Влахов С., Флорин С. Непереводимое в переводе. М.: Международные отношения. 1980. 343 с.

3. Выготский Л. С. Психология искусства. М.: Лабиринт. 1997. 416 с.

4. Колесник О. Комічне в перекладі. Філософія в Україні. 2006. № 10. С. 103-110.

5. Кржижановский С. Д. Поэтика заглавий. М.: Никитинские субботники. 1931.32 с.

6. Кухаренко В. А. Интерпретация текста: учеб. пособие. М.: Просвещение. 1988. 192 с.

7. Нестерова М. Н., Папулова Ю. К. «The Lambs of London» и / или «Лондонские сочинители»: о проблеме перевода заглавия. Вестник Московского университета. Сер. 22. 2014. № 3. С. 89-101.

8. Підгрушна О. Г. Відтворення англійського гумору в українському художньому перекладі: дис... канд. філ. наук: 10.02.16 / Київський національний університет імені Тараса Шевченка. Київ, 2015. 227 с.

9. Эко У. Заметки на полях «Имени розы» / Пер. с итал. Е. Костюкович. М.: Астрель, Corpus. 2012. 160 с.

10. Etkind, А. Поэтика заглавий. Revue des études slaves. 1998. Tome 70. Fascicule 3. L'espace poetique. En hommage à Efim Etkind. P. 559-565.

11. Zabalbeascoa, P. Humor and Translation - An Interdiscipline. Humor: International Journal of Humor Research. 2005. Vol. 18/2. P. 185-207.

DOI https://doi.org/10.30525/978-9934-26-110-7-61

\section{ОСОБЛИВОСТІ ПЕРЕКЛАДУ ОФІЦІЙНО-ДІЛОВОГО СТИЛЮ МОВЛЕННЯ}

\author{
Долинський $\mathbf{\epsilon}$. В. \\ доктор педагогічних наук, \\ професор кафедри германської філології та перекладознавства \\ Хмельницький національний університет \\ м. Хмельницький, Украӥна
}

Офіційно-діловий стиль - функціональний різновид мови, який слугує для спілкування в державно-політичному, громадському й 
економічному житті, законодавстві, у сфері управління адміністративногосподарською діяльністю. Належить до виразно-об'єктивних стилів; вирізняється найвищою мірою книжності. Основне призначення регулювати офіційні ділові відносини в зазначених вище сферах та обслуговувати громадянські потреби людей у типових ситуаціях $[3 ; 5]$.

Формулюючи поняття «ділова мова», слід мати на увазі принаймні три сучасні стилі: офіційно-діловий, науковий, розмовний, оскільки ділова мова містить близькі, взаємопов'язані й навіть спільні мовні засоби різних рівнів. Уміле використання цих засобів є безперечною умовою досягання успіхів у професійній сфері.

Високорозвинена сучасна мова має розгалужену систему стилів, серед яких: розмовний, художній, науковий, публіцистичний, епістолярний, офіційно-діловий і конфесійний. Для виділення стилів мовлення важливе значення мають форми мови - усна й писемна, розмовна i книжна. Усі стилі мають усну й писемну форми, хоча усна форма більш притаманна розмовному стилю, а іншим - переважно писемна. Оскільки останні сформувалися на книжній основі, їх називають книжними. Структура текстів різних стилів неоднакова. Якщо для розмовного стилю характерний діалог (полілог), то для інших це здебільшого монолог [5].

Під функціональним різновидом мови слід розуміти систему мовних одиниць, способів їх виокремлення та використання, визначених соціальними завданнями. Мовленню у сфері управління притаманна низка специфічних особливостей. Учасниками ділового спілкування є органи та ланки управління, організації, заклади, підприємства, посадовці, працівники. Характер і зміст інформаційних зв'язків залежать від місця установи в ієрархії органів управління, її компетенції, функціонального змісту діяльності. Ці стосунки стабільні й регламентуються чинними правовими нормами.

Особливість ділового спілкування полягає в тому, що незалежно від того, хто є безпосереднім укладачем документа й кому безпосередньо його адресовано, офіційним автором та адресатом документа майже завжди є організація в цілому.

Наступною характерною рисою ділового спілкування $є$ тематична обмеженість кола завдань, що розв'язує організація, а це, у свою чергу, є наслідком певної стабільності їі функцій. Отже, можна вирізнити такі властивості управлінської інформації в умовах ділового спілкування: офіційний характер; адресність; повторність; тематична обмеженість.

Специфіка офіційно-ділового стилю мовлення полягає в певних стильових рисах (ознаках) що притаманні лише йому, а саме: нейтральний тон викладу змісту лише у прямому значенні; точність та ясність повинні поєднуватися $з$ лаконічністю, стислістю й послідовністю 
викладу фактів; документальність (кожний офіційний папір повинен мати характер документа), наявність реквізитів, котрі мають певну черговість, що дозволяє довго зберігати традиційні стабільні форми; наявність усталених одноманітних мовних зворотів, висока стандартизація вислову; сувора регламентація тексту; для чіткої організації текст поділяється на параграфи, пункти, підпункти [4].

Ці основні риси є визначальними у формуванні системи мовних одиниць і прийомів їх використання в текстах ділових (управлінських) документів.

У результаті багатовікового розвитку в офіційно-діловому стилі сформувалися такі мовні засоби та способи викладу змісту, які дозволяють найефективніше фіксувати управлінську інформацію й відповідати всім вимогам, що до неї висуваються, а саме: 1) широке використовування суспільно-політичної та адміністративно-канцелярської термінології (комплектування бази даних, регламентація дій, функціювання закладу); 2) наявна фразеологія повинна мати специфічний характер (брати участь, висунути пропозицію, підбивати баланс, ініціювати питання, ставити питання); 3) обов'язкова відсутність будь-якої авторської мовної індивід дуальності та емоційно-експресивної лексики; 4) синонімія має бути зведена до мінімуму й не викликати двозначності сприймання; 5) наявність безособових і наказових форм дієслів у формі теперішнього часу із зазначенням послідовності, постійності дії; 6) чітко регламентоване розміщення та будова тексту; обсяг основних частин, наявність обов'язкових стандартних стійких висловів, певних кліше (що дозволяє користуватися готовими бланками) $[2 ; 3]$.

Офіційно-діловий стиль має такі функціональні підстилі:

1. Законодавчий - використовується в законотворчій сфері, регламентує та обслуговує офіційно-ділові стосунки між приватними особами, між державою і приватними та службовими особами. Реалізується в Конституції, законах, указах, статутах, постановах тощо.

2. Дипломатичний - використовується у сфері міждержавних офіційно-ділових стосунків у галузі політики, економіки, культури. Регламентує офіційно-ділові стосунки міжнародних організацій, структур, окремих громадян. Реалізується в конвенціях (міжнародних угодах), комюніке (повідомленнях), нотах (зверненнях), протоколах, меморандумах, договорах, заявах, ультиматумах та ін.

3. Юридичний - використовується у юриспруденції судочинство, дізнання, розслідування, арбітраж). Цей підстиль обслуговує й регламентує правові та конфліктні відносини: між державою i підприємствами та організаціями всіх форм власності; між підприємствами, організаціями, установами; між державою і приватними 
особами; між підприємствами, організаціями, установами всіх форм власності та приватними особами; між приватними особами. Реалізується в актах, позовних заявах, протоколах, постановах, запитах, повідомленнях тощо.

4. Адміністративно-канцелярський - використовується у професійновиробничій сфері, правових відносинах і діловодстві. Він обслуговує та регламентує: службові (офіційні) відносини між підприємствами одного й різного підпорядкування; службові відносини між структурними підрозділами одного підпорядкування; службові відносини між приватною особою та організацією, установою, закладом і навпаки; приватні (неофіційні) стосунки між окремими громадянами. Реалізується в офіційній кореспонденції (листах), договорах, контрактах, заявах, автобіографіях, характеристиках, дорученнях, розписках тощо [2].

Тексти офіційних документів, як правило, перекладаються за готовою моделлю, оскільки при перекладі переважають однозначні еквіваленти і трансформації [1].

Під час перекладу термінів офіційно-ділового мовлення часто дотримуються головного правила: термін потрібно перекладати терміном. Наприклад, interrogation - допит, motion - клопотання, ці слова мають прямі відповідники в українській мові. Деякі терміни при перекладі зазнають калькування, тобто вони перекладаються за допомогою українських слів і виразів: according to law- відповідно до закону, accompanying document - супроводжуючий документ. Частина термінів, що мають міжнародний характер, передаються на українську мову шляхом транслітерації: vice-consul - віце-консул, legitimism легітимізм. Такі терміни, як immunity agreement -згода про співпрацю із судом, bail bondsman - поручитель під заставу, були перекладені описовим способом, оскільки для них немає прямого відповідника.

Отже, офіційно-діловий стиль мовлення - це сукупність мовних засобів, призначених для регулювання ділових стосунків, спілкування на державно-політичному, громадському, економічному рівні, у законодавстві, сфері управління адміністративно-господарською діяльністю (офіційно-ділова мовна сфера). Він має сферу свого використання та лише йому притаманні перекладознавчі ознаки.

\section{Література:}

1. Ларкін С., Денисенко Н. Особливості англо-українського перекладу юридичних текстів. URL: https://lmsapi.plagiat.pl/preview/largeresult/zbirnyk-naukovyh-statej-Mova.-Svidomist.-Kontsept-vyp.-10..pdf?key= 01586b9a-5158-4a42-a26f-080f60aedd20 (дата звернення: 28.06.2021) 
2. Особливості використання офіційно-ділового стилю при оформленні різного виду ділових документів. URL: https://postulat.info/ postulates/dokumentoznavstvo-ta-dilovodstvo/osoblyvosti-vykorystannyaofitsijno-dilovogo-stylyu-pry-oformlenni-riznogo-vydu-dilovyh-dokumentiv/ (дата звернення: 29.06.2021);

3. Особливості перекладу економічних та юридичних документів на матеріалах угод, контрактів, договорів та ділових листів. URL: 45/3c0a65635a3bc69a4d43b88421306c26_0.html (дата звернення: 29.06.2021)

4. Офіційно-діловий стиль: основні ознаки. URL: https://osvita.ua/ vnz/reports/dilovodstvo/24266/ (дата звернення: 28.06.2021);

5. Стилі літературної української мови як різновиди мови. URL: https://osvita.ua/vnz/reports/dilovodstvo/24233/ ) (дата звернення: 27.06.2021).

DOI https://doi.org/10.30525/978-9934-26-110-7-62

\title{
USE OF MULTIMEDIA TEACHING TOOLS IN THE STUDY APPROACH FOR FUTURE TRANSLATORS
}

\author{
Karachova D. V. \\ PhD in Philology
}

Senior lecturer at the Department of Business Foreign Language and Translation

National Technical University «Kharkiv Polytechnic Institute»

\section{Prytychenko H. V.}

Lecturer at the Department of Business Foreign Language and Translation National Technical University «Kharkiv Polytechnic Institute»

\author{
Ahibalova T. M. \\ PhD in Philology \\ Associate Professor at the Department of Business Foreign Language and \\ Translation \\ National Technical University «Kharkiv Polytechnic Institute» \\ Kharkiv, Ukraine
}

The modern world tends to combine the latest technologies and everyday life, and education is no exception. In our opinion, nowadays it is impossible 